\title{
Tillage, Desmodium intortum, Fertilizer Rates for Carbon Stock, Soil Quality and Grain Yield in Northern Guinea Savanna of Nigeria
}

\author{
Odunze Azubuike Chidowe1, Asholo David Blessing1, Ogunwole Joshua Olalekan², \\ Oyinlola Eunice Yetunde ${ }^{1}$, Chinke Nkechi Mary ${ }^{1}$ \\ ${ }^{1}$ Department of Soil Science/Institute for Agricultural Research, Ahmadu Bello University, Zaria, Nigeria \\ ${ }^{2}$ BOWEN University, Iwo, Ado Ekiti State, Nigeria \\ Email: odunzeac@gmail.com
}

How to cite this paper: Odunze, A.C., Asholo David, B., Ogunwole, J.O., Oyinlola, E.Y. and Chinke, N.M. (2019) Tillage, Desmodium intortum, Fertilizer Rates for Carbon Stock, Soil Quality and Grain Yield in Northern Guinea Savanna of Nigeria. American Journal of Climate Change, $\mathbf{8}$, 325-341.

https://doi.org/10.4236/ajcc.2019.82018

Received: March 22, 2019

Accepted: June 25, 2019

Published: June 28, 2019

Copyright $\odot 2019$ by author(s) and Scientific Research Publishing Inc. This work is licensed under the Creative Commons Attribution-NonCommercial International License (CC BY-NC 4.0). http://creativecommons.org/licenses/by-nc/4.0/ (c) (i) \& Open Access

\begin{abstract}
Northern Guinea Savanna of Nigeria soils are continuously and intensively cultivated, resulting in soil quality degradation, carbon stock depletion, accelerated soil erosion and soil nutrient depletion. Effects of land use change on soil carbon stocks (SOC) are of concern regarding greenhouse gas emissions mitigation and sustainable crop production, because there is a need for food sufficiency while conserving the environment. Also, managing soils under intensive use and restoring degraded soils are top priorities for a sustained agronomic production while conserving soil and water resources. Hence, this study; "Tillage, Desmodium intortum, fertilizer rates for carbon stock, soil quality and grain yield in Northern Guinea Savanna" is aimed at devising possible mitigating measures for soil quality degradation, carbon stock depletion and impoverished crop yields using Zea mays as test crop. The study was a Randomized Complete Block Design (RCBD) in split-split plot arrangement with four replicates. The four main tillage and Desmodium intortum combination treatments were: 1) Maize - without Desmodium + Conventional tillage (MC), 2) Maize + Desmodium live-mulch incorporated and relayed + Conservation tillage (MDIC), 3) Maize + Desmodium in no-tillage system (MDNT), 4) Maize + Desmodium in strip tillage (MDST). The main treatment plots were each divided to accommodate four (4) rates of $\mathrm{N}(60,80,100$ and $120 \mathrm{~kg} \cdot \mathrm{ha}^{-1}$ ) as sub plots, while the $\mathrm{N}$ rate plots were further divided to accommodate three (3) rates of $\mathrm{P}\left(6.6,13.2\right.$, and $\left.26.4 \mathrm{~kg} \cdot \mathrm{ha}^{-1}\right)$ as sub-subplots. Findings support that Desmodium intercrops with Maize treatments (MDIC, MDNT, and MDST) resulted in increased organic carbon contents in 2013, with MDNT resulting in significantly higher organic carbon content (7.37 $\mathrm{g} \cdot \mathrm{kg}^{-1}$ in 2012 and $8.37 \mathrm{~g} \cdot \mathrm{kg}^{-1}$ in 2013) than the other treatments. Also, zero
\end{abstract}


tillage practice (MDNT) sequestered significantly higher carbon stock (18.06 t $\mathrm{C} \mathrm{ha}^{-1}$ ), followed by minimum tillage (MDIC) that sequestered $15.99 \mathrm{t} \mathrm{C} \mathrm{ha}^{-1}$ than the other treatments. Highest grain yield of 2.61 tha $^{-1}$ under MDIC and MDNT was followed by MDST and least under MC. Total score of soil quality assessment gave least score values of 13 under MDIC and MDNT; thus best soil quality $\left(\mathrm{SQ}_{1}\right)$ was ascribed to the minimum tillage with $D$. intortum intercrop and relayed (MDIC) and Zero tillage with $D$. intortum (MDNT) treatments. Maize Strip cropped with D. intortum treatment (MDST) was ranked $\mathrm{SQ}_{2}$.

\section{Keywords}

Carbon Stock, Tillage, Soil Quality, Grain Yield, Climate Change Mitigation

\section{Introduction}

Soils of Northern Guinea Savanna of Nigeria are continuously and intensively cultivated, resulting in soil quality degradation, carbon stock depletion, accelerated soil erosion and soil nutrient depletion while population and food demand is on the increase [1]. Globally, the effects of land use change on soil carbon stocks (SOC) are of concern in the context of international policy agendas on greenhouse gas emissions mitigation [2] and sustainable crop production, because there is a dare need to produce sufficient food for the world's growing population while conserving the environment. The global soil carbon pool however exceeds biomass pools without taking into account that recent soil degradation has led to losses of between 30 percent and 75 percent of their antecedent soil organic carbon; hence, soil carbon increase offers great mitigation potential [3] [4] [5]. Soil organic carbon (SOC) governs soil structural stability and cation exchange capacity directly through its chemical structure and surface properties and indirectly as a source of energy and nutrients for soil biota [6]. Soil organic matter content has a great impact on soil quality and nutrient cycling to significantly influence soil fertility and productivity [5] [7] [8] [9] [10] [11]. Therefore, prudent use and management of organic matter in soils are more important now than ever before to meet the high demands for food and fiber production and satisfy the needs of an increasing world population and industrialization. Managing soils under intensive use and restoring degraded soils are also top priorities for a sustained agronomic and forestry production while conserving soil and water resources. Hence, this study "Tillage with Desmodium intortum and fertilizer rates for carbon stock and quality improvement of soils in Northern Guinea Savanna" is aimed at devising possible means of ameliorating identified problems using Zea mays as test crop.

The need to maintain and enhance multi-functionality of soil necessitates its improved and prudent management for meeting the needs of present and future 
generations. Also, the extent to which soil stewardship and protection is professed determines the sustainability of land use, adequacy of food supply, the quality of air and water resources and the survival of humankind [2]. Hence, decline in SOC under cropping systems can be minimized if relevant information is available on the impact of different nutrient management systems on SOC in the short and long term regimes. For example, the use of nitrogenous fertilizer alone aggravated the problem of soil acidity by lowering the $\mathrm{pH}$ from 5.8 to 4.7 after 25 years [12] and this would have adverse effect on the soil quality, crop yields and carbon stock. This study therefore will evaluate tillage practices and relevant minimum data set of the soils under maize-based cropping systems with Desmodium intortum intercrop, as well as maize grain yields and carbon stock to determine best-bet soil quality, carbon stock and optimum grain maize yield under the study areas.

Maize production in most smallholder farms in Africa is characterized by intensive cultivation of land (continuously), coupled with low external inputs which results in reduction of soil fertility and productivity as well as its quality [13]. Maize (Zea mays L.), which is a major staple cereal produced in this agro-ecology has high yield potentials and occupies about $40 \%$ of total area covered by arable crops [14]. An estimated 2 - 3 million hectares of land are currently under maize cultivation in Nigeria [15] Enhanced maize production through effective soil and nutrient management therefore, has strong potentials for improving livelihood of small holder farmers as it could mitigate poverty, improve soil quality, carbon stock, mitigate global warming, climate change and ensure environmental sustainability. Maize (Zea mays L.) is a widely consumed cereal crop throughout the world. It is used as a staple food (consumed as a whole grains, couscous, and cooked corn flour). Fermented corn grain is also used for alcohol production, while some companies produce infant's diets from corn. In animal feed, corn is a breeding crop which allows fattening cattle more quickly and thus increases the production of milk from cows [16] in [12]. An important part of corn production is its use for the feeding of poultry [12]. Therefore, emphasis in this study will be on maize-based cropping system in Northern Guinea Savanna of Nigeria.

This study therefore aims to evaluate:

1) The carbon stock distribution pattern and soil quality status of Maize-Desmodium based cropping system;

2) Tillage practices and fertilizer rates of Maize-Desmodium intortum intercrops;

3) Maize grain yield of maize-Desmodium intortum based cropping systems at the best-bet tillage, fertilizer rates.

\section{Materials and Methods}

\subsection{Description of the Study Area}

This study was conducted during the 2012 and 2013 rain-fed cropping seasons at 
the experimental farm of Institute for Agricultural Research (IAR), Samaru, Zaria, Nigeria. The experimental field is located between latitude $11^{\circ} 11^{\prime} 19.3^{\prime \prime} \mathrm{N}$ and longitude $7^{\circ} 37^{\prime} 02^{\prime \prime} \mathrm{E}$, with an altitude of $686 \mathrm{~m}$ above sea level in the Northern Guinea Savanna ecology of Nigeria (Figure 1). Long-term mean annual rainfall of the study area is $986.5 \mathrm{~mm}$ [17], concentrated between May and October with a peak in August. The mean daily air temperature of the area is $24^{\circ} \mathrm{C}$ [18]. Soil type of the study area was classified as Typic Haplustalf \{USDA Soil Taxonomy [19] [20] and Acrisol in the [21] legend. The soils are low in inherent fertility, organic matter, cation exchange capacity (CEC) and dominated by low activity clays [22] [23] [24].

\subsection{Treatments and Soil Sampling Procedures}

The experiment was a Randomized Complete Block Design (RCBD) in split-split plot arrangement with four replicates. The four main tillage and Desmodium intortum combination treatments were: 1) Maize - without Desmodium + Conventional tillage (MC), 2) Maize + Desmodium live-mulch incorporated and

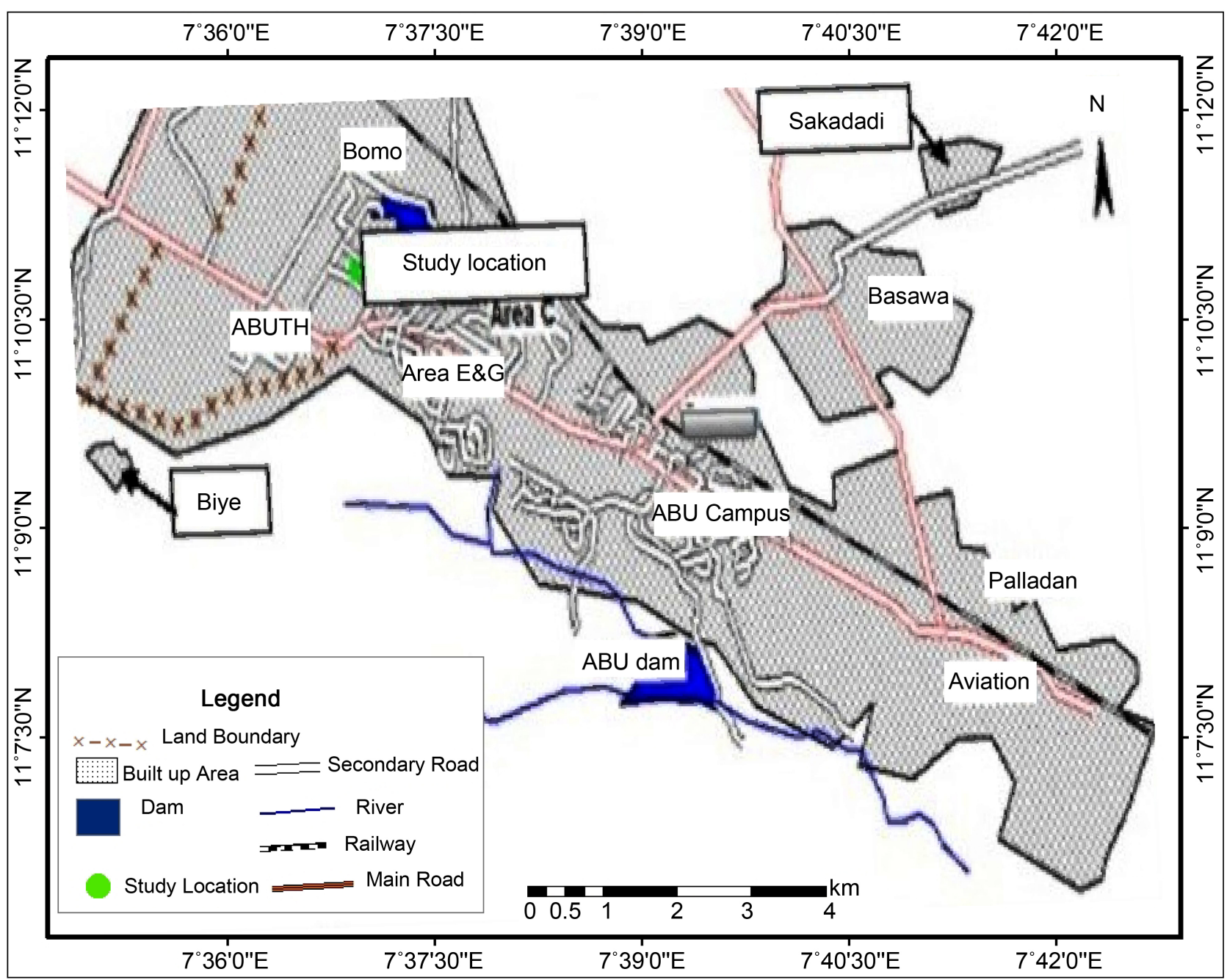

Figure 1. Map of Samaru, Zaria showing the study location. 
relayed + Conservation tillage (MDIC), 3) Maize + Desmodium in no-tillage system (MDNT), 4) Maize + Desmodium in strip tillage (MDST). The main treatment plots were each divided to accommodate four (4) rates of $\mathrm{N}(60,80$, 100 and $120 \mathrm{~kg} \cdot \mathrm{ha}^{-1}$ ) as sub plots, while the $\mathrm{N}$ rate plots were further divided to accommodate three (3) rates of $\mathrm{P}\left(6.6,13.2\right.$, and $\left.26.4 \mathrm{~kg} \cdot \mathrm{ha}^{-1}\right)$ as sub-sub plots. Maize and Desmodium intortum were the planting materials used while urea was the source of nitrogen fertilizer and single super phosphate was the source of phosphorous in this study. Maize (SAMMAZ-14; Quality Protein Maize) seed was obtained from the Institute for Agricultural Research, Ahmadu Bello University (IAR/ABU), Samaru, Zaria, Nigeria while Desmodium intortum seed was sourced from the International Center for Insect Physiology and Ecology (ICIPE) Kenya. Desmodium intortum is a forage legume capable to suppress Striga hermonthica, contributes high biomass and $\mathrm{N}$ to soil, conserve the soil against erosion and moisture depletion and is easy to propagate (by stem cutting and seed) [25] [26] [27] [28]. In 2012 and 2013 and in MC plots, conventional tillage (plowing, harrowing and ridging) was employed. For MDIC plots, manual plowing (with hoe) was done to incorporate Desmodium plants while replanting of Desmodium intortum was done along one side ridge slopes. In the MDNT plots, no tillage was done, while in MDST plots strip tillage of previous year ridges (1/2 ridges) was done using hoe. In MDNT plots, pulverization of soil was made in planting holes and two seeds of maize was planted using local hoe. Maize seeds were planted on ridge peaks at $25 \mathrm{~cm}$ intra-row and $75 \mathrm{~cm}$ inter-row spacing and thinned to one plant per stand two weeks after planting (2 WAP). Desmodium intortum seeds were drilled in bands along ridge slopes in MDIC, MDNT and MDST plots.

In 2012 and 2013 after harvest, a total of 48 soil samples were taken from 0 $15 \mathrm{~cm}$ from the replicates. Samples collected were air-dried, crushed and sieved with a $2 \mathrm{~mm}$ sieve for each treatment. The less than $2 \mathrm{~mm}$ fractions were analyzed for their chemical properties. Result of analysis was used to judge changes in soil quality and carbon stock following second year treatment effect. Soil $\mathrm{pH}$ determination followed the [29] method while organic carbon was determined by wet oxidation method of Walkley and Black [30] method. Soil organic carbon stock (SOC) was measured with the impression:

$$
\mathrm{SOC}=(\mathrm{C} \times \mathrm{D} \times \mathrm{BD} \times 10000) / 1000\left(\mathrm{t} \mathrm{Cha}^{-1}\right)
$$

where $\mathrm{C}=$ organic carbon concentration $\left(\mathrm{g} \cdot \mathrm{kg}^{-1}\right), \mathrm{Bd}=$ bulk density $\left(\mathrm{Mg} \mathrm{m}^{-3}\right)$, depth $=\mathrm{d}(\mathrm{cm})$ and SOC $=$ carbon stock of soil $\left(\mathrm{t} \mathrm{C} \mathrm{ha}^{-1}\right), 10,000 \mathrm{~m}^{2}=1$ ha, and $1000 \mathrm{~kg}=1$ ton [7] [10] [31].

Also, total nitrogen was determined by the regular micro Kjeidahl digestion [32] method and available phosphorus was determined by the [33]; [34] extraction method. Exchangeable bases $(\mathrm{Ca}, \mathrm{Mg}, \mathrm{K}, \& \mathrm{Na})$ were extracted with $1 \mathrm{~N}$ $\mathrm{NH}_{4} 0 \mathrm{Ac}$ [35]. Exchangeable Calcium (Ca) and magnesium ( $\mathrm{Mg}$ ) were determined by EDTA titration methods [36] [37], while potassium (K) and sodium (Na) were determined using flame photometry [38]. Cation exchange capacity 
(CEC) was determined by the $1 \mathrm{~N}$ neutral Ammonium acetate $\left(1 \mathrm{~N} \mathrm{NH}_{4} 0 \mathrm{Ac}\right)$ method [39].

for this study, soil bulk densities were estimated as follows [40]:

$$
\mathrm{BD}=\frac{100}{\frac{\% \mathrm{OM}}{0.244}+\frac{100-\% \mathrm{OM}}{1.64}}
$$

where $\% \mathrm{OM}=$ percentage organic matter content. Conversion factor of matter to organic carbon was taken as 1.724 [30].

Soil Quality:

Basic soil indicators selected for a minimum data set in this study were relevant soil data [41] [42] [43] [44] obtained in this study. This includes: 1) Data on organic carbon, total nitrogen, available phosphorus, cation exchange capacity, bulk density, carbon stock and pH of the soils at crop harvest. 2) Data on maize grain yield for the study period. Soil quality was assessed by using the [45] equation; i.e.,

$$
\mathrm{SQ}=\mathrm{f}(\mathrm{SP}, \mathrm{P}, \mathrm{E}, \mathrm{H}, \mathrm{ER}, \mathrm{BD}, \mathrm{FQ}, \mathrm{MI}) \text {, }
$$

where $\mathrm{SQ}=$ soil quality, $\mathrm{SP}=$ soil properties, $\mathrm{P}=$ potential productivity, $\mathrm{E}=\mathrm{en}$ vironmental factors, $\mathrm{H}=$ Health (Human/animals), $\mathrm{ER}=$ erodibility, $\mathrm{BD}=$ biodiversity, $\mathrm{FQ}=$ food quality and $\mathrm{MI}=$ management input. A score scale of 1 to 5 was used in the assessment of parameters in the model; where 1 is best and 5 is worst condition. Indicator ratings was divided into three groups; namely, more is better was applied to N, P, CEC, SOC and organic carbon, while less is better applied to bulk density and optimum is better was applied to $\mathrm{pH}$. Also, E, H, ER, FQ and MI were each scored 1.0 because the research field used for the experiment had been on a long-term research use (1922 to date) and is being optimally managed to satisfy optimal environmental conditions for sustainability, health factors for human and livestock optimal food quality obtained, biodiversity and input management [11]. Therefore, $\mathrm{SQ}=\mathrm{f}(\mathrm{SP}, \mathrm{P})$ was used to assess quality of soils in this study at the end of rain-fed cropping seasons.

The maize was harvested at physiological maturity and the ears were dehusked, dried and threshed. Maize grain yield at harvest was air-dried for two weeks and weight recorded in tonnes per hectare. Data obtained was subjected to Analysis of variance (ANOVA SAS 9.3 Software [46]. Differences between means were separated using Duncan's Multiple Range Test at 5\% level of probability.

\section{Results and Discussion}

Soils of the study area were dominated with silt fractions $\left(465 \mathrm{~g} \cdot \mathrm{kg}^{-1}\right)$ followed by sand separates $\left(370 \mathrm{~g} \cdot \mathrm{kg}^{-1}\right)$ and clay (Table 1$)$ to be classified as loam in texture. Bulk density of the soils was in the moderate to high value $\left(1.58 \mathrm{Mg} \mathrm{m}^{-3}\right)$, while the reactions were acid ( $\mathrm{pH}$ 5.20). Available phosphorus $\left(5.46 \mathrm{mg} \cdot \mathrm{kg}^{-3}\right.$ ), total nitrogen $\left(0.39 \mathrm{~g} \cdot \mathrm{kg}^{-1}\right)$, organic carbon $\left(5.73 \mathrm{~g} \cdot \mathrm{kg}^{-1}\right)$ and cation exchange capacity $\left(5.00 \mathrm{cmol} \cdot \mathrm{kg}^{-1}\right)$ of the soils were in the low range of values to suggest 
Table 1. Physical and chemical properties of experimental field in 2012 before planting of Maize.

\begin{tabular}{|c|c|c|}
\hline Parameters $(0-15 \mathrm{~cm})$ & Units & Values \\
\hline Particle size: Sand & $\mathrm{g} \cdot \mathrm{kg}^{-1}$ & 370 \\
\hline Silt & $\mathrm{g} \cdot \mathrm{kg}^{-1}$ & 465 \\
\hline Clay & $\mathrm{g} \cdot \mathrm{kg}^{-1}$ & 165 \\
\hline Texture & $\mathrm{g} \cdot \mathrm{kg}^{-1}$ & Loam \\
\hline Bulk density & $\mathrm{Mg} \mathrm{m}^{-3}$ & 1.58 \\
\hline $\mathrm{pH}\left(\mathrm{H}_{2} \mathrm{O}\right)$ & & 5.20 \\
\hline Avail. P & $\mathrm{Mg} \mathrm{kg}^{-1}$ & 5.46 \\
\hline Total N & $\mathrm{g} \cdot \mathrm{kg}^{-1}$ & 0.39 \\
\hline Org. C & $\mathrm{g} \cdot \mathrm{kg}^{-1}$ & 5.73 \\
\hline $\operatorname{CEC}\left(1 \mathrm{~N} \mathrm{NH}_{4} 0 \mathrm{~A}_{\mathrm{C}}\right)$ & $\mathrm{C} \mathrm{mol} \cdot \mathrm{kg}^{-1}$ & 5.00 \\
\hline Exch. Bases & $\mathrm{C} \mathrm{mol} \cdot \mathrm{kg}^{-1}$ & \\
\hline $\mathrm{Ca}$ & $\mathrm{C}$ mol. $\mathrm{kg}^{-1}$ & 0.89 \\
\hline $\mathrm{Mg}$ & $\mathrm{C} \mathrm{mol} \cdot \mathrm{kg}^{-1}$ & 0.60 \\
\hline $\mathrm{K}$ & $\mathrm{C}$ mol. $\mathrm{kg}^{-1}$ & 0.17 \\
\hline $\mathrm{Na}$ & $\mathrm{C} \mathrm{mol} \cdot \mathrm{kg}^{-1}$ & 0.18 \\
\hline
\end{tabular}

that the soils are degraded and impoverished in quality and fertility status [10] [24] [47].

Following experimentation in 2012 and 2013, organic carbon content (Table 2) under conventional tillage with sole maize decreased from $5.95 \mathrm{~g} \cdot \mathrm{kg}^{-1}$ to 5.65 $\mathrm{g} \cdot \mathrm{kg}^{-1}(5.1 \%)$ to suggest that conventional tillage with sole maize (MC) portends degradation of soil, facilitation of global warming and climate change [31] [47]. However, the Desmodium intercrops with Maize treatments (MDIC, MDNT, and MDST) resulted in increased organic carbon contents in 2013, with MDNT (Zero tillage planted with Desmodium intortum and Maize) resulting in significantly $(\mathrm{P}<0.05)$ higher organic carbon content $\left(7.37 \mathrm{~g} \cdot \mathrm{kg}^{-1}\right.$ in 2012 and 8.37 $\mathrm{g} \cdot \mathrm{kg}^{-1}$ in 2013) than the other treatments (Table 2). This would suggest that Desmodium intercrop with maize under minimum and zero tillage practices would sequester more organic carbon in soils, improve soil quality and fertility, as well as combat global warming and climate change. Inorganic nitrogen fertilizer rates' use for maize production in this study (Table 2) show that whereas $80 \mathrm{~kg} \mathrm{~N} \mathrm{ha}^{-1}$ increased organic carbon in soil from 2012 value $\left(6.71 \mathrm{~g} \cdot \mathrm{kg}^{-1}\right)$ to 2013 value $\left(6.73{\left.\mathrm{~g} \cdot \mathrm{kg}^{-1}\right), 100 \mathrm{~kg} \mathrm{~N} \mathrm{ha}}^{-1}\right.$ sequestered sustainably higher organic carbon in $2012\left(6.6 \mathrm{~g} \cdot \mathrm{kg}^{-1}\right)$ to $2013\left(7.62 \mathrm{~g} \cdot \mathrm{kg}^{-1}\right)$, to suggest that under this technology, $100 \mathrm{~kg} \mathrm{~N} \mathrm{ha}^{-1}$ could be preferred for use in maize cultivation over other rates. The $26.4 \mathrm{~kg} \mathrm{P} \mathrm{ha}^{-1}$ phosphorus fertilizer rate sequestered significantly $(\mathrm{P}<$ 0.05 ) higher organic carbon $\left(6.54 \mathrm{~g} \cdot \mathrm{kg}^{-1}\right)$ in 2012 that increased to $6.91 \mathrm{~g} \cdot \mathrm{kg}^{-1}$ in 2013, despite that $13.2 \mathrm{~kg} \mathrm{P} \mathrm{ha}^{-1}$ sequestered significantly higher Phosphorus in $2012\left(6.78 \mathrm{mg} \cdot \mathrm{kg}^{-1}\right)$ but increased to $6.86 \mathrm{mg} \cdot \mathrm{kg}^{-1}$ in 2013 that was significantly lower than value sequestered by $26.4 \mathrm{~kg} \mathrm{P} \mathrm{ha}^{-1}$ in 2013 (Table 2). Therefore, the 
Table 2. Effect of Tillage, $\mathrm{N}$ and $\mathrm{P}$ fertilizer rates on Organic carbon, Bulk Density and Carbon stock at $0-15 \mathrm{~cm}$ depth.

\begin{tabular}{|c|c|c|c|c|c|c|c|c|c|}
\hline \multirow[t]{3}{*}{ Tillage } & \multicolumn{2}{|c|}{ Organic carbon } & \multirow[t]{2}{*}{ Combined } & \multicolumn{2}{|c|}{ Organic matter } & \multirow[t]{2}{*}{ Combined } & \multicolumn{2}{|c|}{ Bulk Density } & \multirow[t]{2}{*}{ Mean } \\
\hline & 2012 & 2013 & & 2012 & 2013 & & 2012 & 2013 & \\
\hline & \multicolumn{3}{|c|}{$\mathrm{g} \cdot \mathrm{kg}^{-1}$} & \multicolumn{3}{|c|}{$\%$} & \multicolumn{3}{|c|}{$\mathrm{Mg} \mathrm{m}^{-3}$} \\
\hline MC & $5.95 c$ & $5.65 c$ & $5.80 \mathrm{c}$ & $1.04 \mathrm{c}$ & $0.97 \mathrm{c}$ & $1.0 \mathrm{c}$ & 1.55 & 1.55 & 1.55 \\
\hline MDIC & $6.68 \mathrm{~b}$ & $7.15 b$ & $6.92 b$ & $1.15 \mathrm{~b}$ & $1.23 \mathrm{~b}$ & $1.19 \mathrm{~b}$ & 1.54 & 1.53 & 1.54 \\
\hline MDNT & $7.37 \mathrm{a}$ & $8.37 \mathrm{a}$ & $7.87 \mathrm{a}$ & $1.27 \mathrm{a}$ & $1.44 \mathrm{a}$ & $1.36 \mathrm{a}$ & 1.53 & 1.52 & 1.53 \\
\hline MDST & $5.98 \mathrm{c}$ & $6.22 \mathrm{c}$ & $6.06 \mathrm{c}$ & $1.03 \mathrm{c}$ & $1.07 \mathrm{c}$ & $1.05 \mathrm{c}$ & 1.55 & 1.55 & 1.55 \\
\hline S.E \pm & 0.03 & 0.03 & 0.03 & 0.03 & 0.03 & 0.03 & 0.03 & 0.03 & 0.03 \\
\hline \multicolumn{10}{|c|}{ N Level $\left(\mathrm{kg} \mathrm{N} \mathrm{ha}^{-1}\right)$} \\
\hline 60 & $6.42 \mathrm{ab}$ & $6.44 \mathrm{~b}$ & $6.43 c$ & $1.11 \mathrm{ab}$ & $1.11 \mathrm{~b}$ & $1.11 \mathrm{c}$ & 1.54 & 1.54 & 1.54 \\
\hline 80 & $6.71 \mathrm{a}$ & $6.73 \mathrm{ab}$ & $6.72 b$ & $1.16 \mathrm{a}$ & $1.16 \mathrm{~b}$ & $1.16 \mathrm{~b}$ & 1.54 & 1.54 & 1.54 \\
\hline 100 & $6.60 \mathrm{a}$ & $7.62 \mathrm{a}$ & $7.11 \mathrm{a}$ & $1.14 \mathrm{a}$ & $1.31 \mathrm{a}$ & $1.23 \mathrm{a}$ & 1.54 & 1.53 & 1.54 \\
\hline 120 & $6.24 \mathrm{~b}$ & $6.60 \mathrm{~b}$ & $6.42 \mathrm{c}$ & $1.08 \mathrm{~b}$ & $1.14 \mathrm{~b}$ & $1.11 \mathrm{c}$ & 1.55 & 1.54 & 1.55 \\
\hline S.E \pm & 0.03 & 0.03 & 0.03 & 0.03 & 0.03 & 0.03 & 0.03 & 0.03 & 0.03 \\
\hline \multicolumn{10}{|c|}{ P Levels (kg P ha ${ }^{-1)}$} \\
\hline 6.6 & $6.15 c$ & $6.78 \mathrm{c}$ & $6.47 \mathrm{c}$ & $1.06 \mathrm{c}$ & 1.17 & $1.12 \mathrm{~b}$ & 1.55 & 1.54 & 1.54 \\
\hline 13.2 & $6.78 \mathrm{a}$ & $6.86 \mathrm{~b}$ & $6.82 \mathrm{a}$ & $1.17 \mathrm{a}$ & 1.18 & $1.18 \mathrm{a}$ & 1.54 & 1.54 & 1.54 \\
\hline 26.4 & $6.54 b$ & $6.91 \mathrm{a}$ & $6.73 b$ & $1.13 \mathrm{~b}$ & 1.19 & $1.16 \mathrm{a}$ & 1.54 & 1.54 & 1.54 \\
\hline S.E \pm & 0.03 & 0.03 & 0.03 & 0.03 & 0.03 & 0.03 & 0.03 & 0.03 & 0.03 \\
\hline \multicolumn{10}{|c|}{ Interaction } \\
\hline $\mathrm{T} \times \mathrm{N}$ & $* *$ & NS & * & $* *$ & NS & $* *$ & NS & NS & NS \\
\hline $\mathrm{T} \times \mathrm{P}$ & $* *$ & NS & NS & $* *$ & NS & $* *$ & NS & NS & NS \\
\hline $\mathrm{N} \times \mathrm{P}$ & $* *$ & NS & * & $* *$ & NS & $* *$ & NS & NS & NS \\
\hline $\mathrm{T} \times \mathrm{N} \times \mathrm{P}$ & $* *$ & $* *$ & * & $* *$ & NS & $* *$ & NS & NS & NS \\
\hline
\end{tabular}

Means with the same letter are not statistically different at $5 \%$ level of significance, ${ }^{*}=$ significant.

intercrop of Maize with Desmodium intortum under minimum tillage (MDIC and MDST) and zero tillage practices using $100 \mathrm{~kg} \mathrm{~N} \mathrm{ha}^{-1}$ and $26.4 \mathrm{~kg} \mathrm{P} \mathrm{ha}^{-1}$ interacted to impact improved soil quality, fertility and crop production, controlled global warming and climate change.

Significantly improved soil organic matter content under the minimum tillage (MDIC \& MDST) and zero tillage (MDNT) treatments when compared with conventional tillage with maize sole cropping (MC) would account for the reduced bulk density values under the minimum tillage practices (Table 2) though not significantly different. This suggests that sequestered carbon in soil under the minimum and zero tillage practices would also cause a reduction in soil bulk density as an attribute of improved soil health/quality.

Calculated soil carbon stock from mean organic carbon and bulk density of the soil at depth $0-15 \mathrm{~cm}$ (Table 3) reveals that zero tillage practice (MDNT) sequestered significantly $(\mathrm{P}<0.05)$ higher carbon stock $\left(18.06 \mathrm{t} \mathrm{C} \mathrm{ha}^{-1}\right)$, followed by minimum tillage (MDIC) that sequestered $15.99 \mathrm{t} \mathrm{C} \mathrm{ha}^{-1}$ than the other 
Table 3. Effect of Tillage, $\mathrm{N}$ and $\mathrm{P}$ fertilizer rates on Bulk Density, Organic Carbon and Carbon Stock over the $0-15 \mathrm{~cm}$ depth: 2012-2013.

\begin{tabular}{|c|c|c|c|}
\hline Tillage & Mean Organic Carbon & Mean Bulk Density & SOC \\
\hline & $\mathrm{g} \cdot \mathrm{kg}^{-1}$ & $\mathrm{Mg} \mathrm{m}^{-3}$ & $\mathrm{tCha}^{-1}$ \\
\hline MC & $5.80 \mathrm{c}$ & 1.55 & $13.49 d$ \\
\hline MDIC & $6.92 b$ & 1.54 & $15.99 \mathrm{~b}$ \\
\hline MDNT & $7.87 \mathrm{a}$ & 1.53 & $18.06 \mathrm{a}$ \\
\hline MDST & $6.06 c$ & 1.55 & $14.09 \mathrm{c}$ \\
\hline \multicolumn{4}{|c|}{ N Levels } \\
\hline 60 & $6.43 c$ & 1.54 & $14.85 \mathrm{c}$ \\
\hline 80 & $6.72 b$ & 1.54 & $15.52 \mathrm{~b}$ \\
\hline 100 & $7.11 \mathrm{a}$ & 1.54 & $16.42 \mathrm{a}$ \\
\hline 120 & $6.42 c$ & 1.55 & $14.93 c$ \\
\hline \multicolumn{4}{|c|}{ P Levels } \\
\hline 6.6 & $6.47 c$ & 1.54 & $14.95 \mathrm{~b}$ \\
\hline 13.2 & $6.82 \mathrm{a}$ & 1.54 & $15.75 \mathrm{a}$ \\
\hline 26.4 & $6.73 b$ & 1.54 & $15.55 \mathrm{a}$ \\
\hline
\end{tabular}

Means with the same letter are not statistically different at $5 \%$ level of significance, ${ }^{\star}=$ significant.

treatments. Also, $100 \mathrm{~kg} \mathrm{~N} \mathrm{ha}^{-1}$ and $26 \mathrm{~kg} \mathrm{P} \mathrm{ha}^{-1}$ sequestered significantly higher carbon stock in soils than the other treatments to suggest this minimum tillage and/or zero tillage practices for farmer adoption and environmental sustainability.

Table 4 reveals sole maize with conventional tillage (MC) resulted in significant acidification of the soil ( $\mathrm{pH}$ 5.20) in 2012 more than the other treatments. However in 2013, MC treatment resulted in better acid condition for nutrient uptake ( $\mathrm{pH}$ 5.60) than other treatments though not significantly. The $100 \mathrm{~kg} \mathrm{~N}$ $\mathrm{ha}^{-1}$ fertilizer rate best modified soil reaction ( $\mathrm{pH}$ 5.39) than other treatments in 2012 , but in $2013,80 \mathrm{~kg} \mathrm{~N} \mathrm{ha}^{-1}$ significantly $(\mathrm{P}<0.05)$ modified soil reaction better than the other treatments (Table 4). Phosphorus fertilizer rates appear not to have affected soil pH in 2012 and 2013 under this study (Table 4).

Total nitrogen in soils after harvest in 2012 and 2013 was least under MC treatment, while MDNT contributed significantly $(\mathrm{P}<0.05)$ higher nitrogen values in both years (Table 4). Total nitrogen in soil was significantly higher under 80 and $100 \mathrm{~kg} \mathrm{~N} \mathrm{ha}^{-1}$ rates in 2012 than other treatments, but in 2013, $\mathrm{N}$-rates did not result in any statistical difference. The $26.4 \mathrm{~kg} \mathrm{P}^{-1}$ rate interacted to cause significant nitrogen deposit $\left(0.60 \mathrm{~g} \cdot \mathrm{kg}^{-1}\right)$ in soil than the other rates in 2012, but $6.6 \mathrm{~kg} \mathrm{P} \mathrm{ha}^{-1}$ contributed significant nitrogen deposit in soil $\left(0.66 \mathrm{~g} \cdot \mathrm{kg} \cdot \mathrm{ha}^{-1}\right)$ than the other rates in 2013. Perhaps, nitrogen fertilizer applied under MC was not adequately exploited by plants, thus leaving higher nitrogen not utilized in the soil than other tillage treatments.

Available phosphorus in soil after harvest in 2012 and 2013 was significantly $(\mathrm{P}>0.05)$ higher under MDIC (Table 4). Perhaps, this could partly be attributed 
Table 4. Effect of Tillage, N and P fertilizer rates on pH, Total N, Avail P, and CEC on Soil in 2012 and 2013.

\begin{tabular}{|c|c|c|c|c|c|c|c|c|}
\hline \multirow[t]{2}{*}{ Tillage } & \multicolumn{2}{|c|}{ Soil pH $\left(\mathrm{H}_{2} \mathrm{O}\right)$} & \multicolumn{2}{|c|}{ Total N (g.kg $\left.{ }^{-1}\right)$} & \multicolumn{2}{|c|}{ Avail P (mg.kg-1) } & \multicolumn{2}{|c|}{$\mathrm{CEC}\left(\mathrm{cmol} \cdot \mathrm{kg}^{-1}\right)$} \\
\hline & 2012 & 2013 & 2012 & 2013 & 2012 & 2013 & 2012 & 2013 \\
\hline MC & $5.20 \mathrm{c}$ & $5.60 \mathrm{a}$ & $0.51 \mathrm{c}$ & $0.52 \mathrm{c}$ & $5.63 c$ & $3.84 \mathrm{c}$ & 0.69 & $0.59 \mathrm{c}$ \\
\hline MDIC & $5.41 \mathrm{a}$ & $5.44 \mathrm{a}$ & $0.61 b$ & $0.61 b$ & $6.50 \mathrm{a}$ & $7.84 \mathrm{a}$ & 0.79 & $1.86 \mathrm{a}$ \\
\hline MDNT & $5.30 \mathrm{~b}$ & $5.53 a$ & $0.72 \mathrm{a}$ & $0.81 \mathrm{a}$ & $6.14 \mathrm{~b}$ & $7.43 a$ & 0.78 & $2.02 \mathrm{a}$ \\
\hline MDST & $5.32 \mathrm{~b}$ & $5.50 \mathrm{a}$ & $0.50 \mathrm{c}$ & $0.55 \mathrm{c}$ & $5.72 \mathrm{c}$ & $5.37 \mathrm{~b}$ & 0.72 & $1.06 \mathrm{~b}$ \\
\hline $\mathrm{SE} \pm$ & 0.02 & 0.06 & 0.02 & 0.002 & 0.1 & 0.3 & 0.05 & 0.15 \\
\hline \multicolumn{9}{|c|}{$\mathrm{N}$ level $\left(\mathrm{kg} \mathrm{N} \mathrm{ha}^{-1}\right)$} \\
\hline 60 & $5.30 \mathrm{~b}$ & $5.43 \mathrm{~b}$ & $0.57 b$ & 0.61 & $5.40 \mathrm{c}$ & $5.17 \mathrm{c}$ & $0.63 b$ & $1.10 \mathrm{~b}$ \\
\hline 80 & $5.32 \mathrm{~b}$ & $5.66 \mathrm{a}$ & $0.65 a$ & 0.62 & $5.99 b$ & $6.59 \mathrm{~b}$ & $0.73 a$ & $1.50 \mathrm{ab}$ \\
\hline 100 & $5.39 \mathrm{a}$ & $5.58 \mathrm{ab}$ & $0.62 \mathrm{a}$ & 0.63 & $7.08 \mathrm{a}$ & $7.79 \mathrm{a}$ & $0.86 a$ & $1.72 \mathrm{a}$ \\
\hline 120 & $5.23 \mathrm{c}$ & $5.47 \mathrm{~b}$ & $0.51 \mathrm{c}$ & 0.63 & $5.53 \mathrm{c}$ & $4.94 \mathrm{c}$ & $0.75 \mathrm{ab}$ & $1.20 \mathrm{~b}$ \\
\hline $\mathrm{SE} \pm$ & 0.02 & 0.06 & 0.02 & 0.002 & 0.1 & 0.3 & 0.05 & 0.15 \\
\hline \multicolumn{9}{|c|}{ P level (kg P ha- $\left.{ }^{-1}\right)$} \\
\hline 6.6 & $5.28 \mathrm{a}$ & $5.52 \mathrm{a}$ & $0.56 \mathrm{c}$ & $0.66 \mathrm{a}$ & $5.71 \mathrm{~b}$ & $5.85 \mathrm{~b}$ & $0.70 \mathrm{~b}$ & 1.42 \\
\hline 13.2 & $5.31 \mathrm{a}$ & $5.53 a$ & $0.59 b$ & $0.61 \mathrm{ab}$ & $5.58 \mathrm{a}$ & $6.67 \mathrm{a}$ & $0.84 \mathrm{a}$ & 1.33 \\
\hline 26.4 & $5.33 \mathrm{a}$ & $5.56 \mathrm{a}$ & $0.60 \mathrm{a}$ & $0.59 b$ & $5.70 \mathrm{~b}$ & $5.84 \mathrm{~b}$ & $0.69 b$ & 1.39 \\
\hline $\mathrm{SE} \pm$ & 0.02 & 0.05 & 0.01 & 0.002 & 0.09 & 0.26 & 0.04 & 0.13 \\
\hline \multicolumn{9}{|c|}{ Interaction } \\
\hline $\mathrm{T} \times \mathrm{N}$ & ** & NS & $* *$ & $* *$ & $* *$ & $* *$ & * & * \\
\hline $\mathrm{T} \times \mathrm{P}$ & $* *$ & NS & * & $* *$ & NS & $* *$ & $* *$ & NS \\
\hline $\mathrm{N} \times \mathrm{P}$ & $* *$ & NS & $* *$ & $* *$ & NS & $* *$ & $* *$ & NS \\
\hline $\mathrm{T} \times \mathrm{N} \times \mathrm{P}$ & ** & NS & $* *$ & $* *$ & NS & $* *$ & ** & NS \\
\hline
\end{tabular}

Means with the same letter are not statistically different at $5 \%$ level of significance, ${ }^{*}=$ significant at $5 \%,{ }^{* *}=$ significant at $1 \%, \mathrm{NS}=$ not significant, $\mathrm{T}=$ tillage, $\mathrm{MC}=$ maize-without Desmodium in conventional tillage, $\mathrm{MDIC}=$ maize + Desmodium incorporated and relayed in conservation tillage, $\mathrm{MDNT}=$ maize + Desmodium in no-tillage, MDST $=$ maize + Desmodium in strip tillage.

to Phosphorus deposited from decomposed roots of maize and Desmodium, Desmodium biomass incorporated at land preparation and Phosphorus fertilizer applications not utilized by plants. The low available phosphorus under MC in 2012 and 2013 could be partly attributed to plant uptake and soil erosion. Soil erosion is pronounced under maize mono cropping [48] [49]. Available phosphorus under MDNT increased from its value in $2013\left(6.14 \mathrm{mg} \cdot \mathrm{kg}^{-1}\right.$ in 2012 and $7.43 \mathrm{mg} \cdot \mathrm{kg}^{-1}$ in 2013), perhaps due to decomposed Desmodium biomass of 2012. Also, $100 \mathrm{~kg} \mathrm{~N} \mathrm{ha}^{-1}$ fertilizer rate resulted in $7.79 \mathrm{~g} \cdot \mathrm{kg}^{-1}$ nitrogen deposit in 2012 and $7.79 \mathrm{~g} \cdot \mathrm{kg}^{-1}$ nitrogen in 2013 to perform significantly better than the other rates, but was followed by $80 \mathrm{~kg} \mathrm{~N} \mathrm{ha}^{-1}$ rate (Table 4).

Similarly, $13.2 \mathrm{~kg} \mathrm{P} \mathrm{ha}^{-1}$ rate significantly contributed higher phosphorus to the soil in 2012 and 2013, than the other rates (Table 4).

Cation exchange capacity of the soil was very low generally and not significantly different in 2012. However, in 2013, MDNT treatment (zero tillage) resulted in significantly higher CEC $\left(2.02 \mathrm{C} \mathrm{mol} \mathrm{kg}^{-1}\right)$ than other treatments (Table 
4), but was followed by MDIC. Similarly, $100 \mathrm{~kg} \mathrm{~N} \mathrm{ha}^{-1}$ rate caused significantly higher CEC values in 2012 and 2013 than other $\mathrm{N}$ rates (Table 4). Also, in 2012, $13.2 \mathrm{~kg} \mathrm{P} \mathrm{ha}^{-1}$ resulted in significantly $(\mathrm{P}<0.05)$ higher $\mathrm{CEC}$ value than other $\mathrm{P}$ rates, but the rates were not significantly different in 2013 (Table 4).

Table 5 reveals that in 2012 maize grain yield was not significantly different between tillage treatments, though MDIC resulted in a higher yield $\left(2.18 \mathrm{tha}^{-1}\right)$ than other treatments. In 2013 however, minimum tillage treatments (MDIC \& MDST) and the zero tillage treatments resulted in significantly $(\mathrm{P}<0.05)$ higher grain yields than the sole maize (MC) under conventional tillage. Mean grain yields under the minimum tillage with Desmodium intercrops (MDIC) yielded 2.61 tha $^{-1}$, MDNT yielded 2.57 tha $^{-1}$ and MDST yielded 2.20 tha $^{-1}$ to be preferred for sustainable maize grain production, mitigation of global warming, climate change and environmental conservation over the 2.05 tha $^{-1}$ yield of mono crop maize under conventional tillage (MC).

Nitrogen rates data reveals that $100 \mathrm{~kg} \mathrm{~N} \mathrm{ha}^{-1}$ applications caused significantly higher grain yield $\left(2.67 \mathrm{tha}^{-1}\right)$ in 2012 than the other N-rates and not significantly different yields in 2013. Also, $13.2 \mathrm{~kg} \mathrm{P} \mathrm{ha}^{-1}$ resulted in significantly higher maize grain yields in $2012\left(2.15\right.$ tha $\left.^{-1}\right)$ and 3.03 tha $^{-1}$ in 2013 than other

Table 5. Effect of tillage, $\mathrm{N}$ and $\mathrm{P}$ rates on Maize grain yield in 2012 and 2013.

\begin{tabular}{|c|c|c|c|}
\hline \multirow[t]{2}{*}{ Tillage } & \multicolumn{3}{|c|}{ Grain yield $\left(\right.$ tha $^{-1}$ ) } \\
\hline & 2012 & 2013 & Mean \\
\hline MC & $1.89 \mathrm{a}$ & $2.21 \mathrm{~b}$ & 2.05 \\
\hline MDIC & $2.18 \mathrm{a}$ & $3.04 \mathrm{a}$ & 2.61 \\
\hline MDNT & $2.13 \mathrm{a}$ & $3.00 \mathrm{a}$ & 2.57 \\
\hline MDST & $1.90 \mathrm{a}$ & $2.50 \mathrm{a}$ & 2.20 \\
\hline S.E \pm & 0.15 & 0.04 & \\
\hline \multicolumn{4}{|c|}{ N Level $\left(\mathrm{kg} \mathrm{N} \mathrm{ha}^{-1}\right)$} \\
\hline 60 & $1.92 \mathrm{a}$ & $2.04 \mathrm{c}$ & 1.98 \\
\hline 80 & $2.06 \mathrm{a}$ & $2.72 b$ & 2.39 \\
\hline 100 & $2.08 \mathrm{a}$ & $3.25 \mathrm{a}$ & 2.67 \\
\hline 120 & $1.90 \mathrm{a}$ & $2.58 \mathrm{c}$ & 2.24 \\
\hline S.E \pm & 0.15 & 0.04 & \\
\hline \multicolumn{4}{|c|}{ P Level $\left(\mathrm{kg} \mathrm{P} \mathrm{ha}^{-1}\right)$} \\
\hline 6.6 & $1.80 \mathrm{a}$ & $2.40 \mathrm{~b}$ & 2.10 \\
\hline 13.2 & $2.15 \mathrm{a}$ & $3.03 \mathrm{a}$ & 2.59 \\
\hline 26.4 & $2.02 \mathrm{a}$ & $2.69 \mathrm{~b}$ & 2.36 \\
\hline S.E \pm & 0.13 & 0.04 & \\
\hline \multicolumn{4}{|c|}{ Interaction } \\
\hline $\mathrm{T} \times \mathrm{N}$ & NS & * & \\
\hline $\mathrm{T} \times \mathrm{P}$ & NS & $* *$ & \\
\hline $\mathrm{N} \times \mathrm{P}$ & NS & * & \\
\hline
\end{tabular}


P-rates to be superior in enhancing maize production under this $\mathrm{Ma}$ ize-Desmodium intercrop/Tillage technology.

Table 6 shows the minimum data set (MDS) for soils of the study area and that least bulk density of $1.53 \mathrm{Mg} \mathrm{m}^{-3}$ was observed under the zero tillage with Desmodium intortum intercrop (MDNT) to suggest improved soil condition for crop roots ramification better than mono crop maize production with conventional tillage (MC) and the other tillage treatments. Also, $\mathrm{pH}$ soils at harvest was best under minimum tillage with $D$. intortum incorporated and relayed (MDIC), followed by MDNT (Table 6). Similarly, MDNT resulted in highest organic carbon content in soils when compared with the other treatments, but was followed by MDIC. Also, MDNT, followed by MDIC treatments resulted in highest total nitrogen in soils in this study. Subsequently, MDNT sequestered $18.06 \mathrm{t}$ $\mathrm{Cha}^{-1}$ carbon stock to outperform the other treatments but was followed by MDIC that sequestered $15.99 \mathrm{t} \mathrm{C} \mathrm{ha}^{-1}$. Highest available phosphorus content was contributed by MDIC ( $\left.7.17 \mathrm{mg} \cdot \mathrm{kg}^{-1}\right)$ and was followed by MDNT $\left(6.77 \mathrm{mg} \cdot \mathrm{kg}^{-1}\right)$, while the least available phosphorus was obtained under MC $\left(4.74 \mathrm{mg} \cdot \mathrm{kg}^{-1}\right)$. Cation exchange capacity was best under MDNT, and followed by MDIC (Table 6). The net effect of these physical, biological and chemical interactions on the soil resulted in highest grain yield of 2.61 tha $^{-1}$ under MDIC and MDNT, followed by MDST and least under MC. In summary, total score of the quality assessment gave least score values of 13 under MDIC and MDNT; thus best soil quality $\left(\mathrm{SQ}_{1}\right)$ was ascribed to the minimum tillage with $D$. intortum intercrop and relayed (MDIC) and Zero tillage with D. intortum (MDNT) treatments. Maize Strip cropped with $D$. intortum treatment (MDST) was ranked $\mathrm{SQ}_{2}$ as it was assessed next after $\mathrm{SQ}_{1}$. The Maize under conventional tillage (MC) performed very poorly in the quality assessment and was ranked $\mathrm{SQ}_{3}$.

Table 6. Mean values of Minimum data set of maize-Desmodium/Tillage technology for soil quality assessment.

\begin{tabular}{cccccc}
\hline Parameters & Units & MC & MDIC & MDNT & MDST \\
\hline Bulk density & $\mathrm{Mg} \mathrm{m}^{-3}$ & $1.55(1)$ & $1.54(2)$ & $1.53(3)$ & $1.55(1)$ \\
$\mathrm{pH}$ & & $5.40(4)$ & $5.43(1)$ & $5.42(2)$ & $5.41(3)$ \\
Org. C & $\mathrm{g} \cdot \mathrm{kg}^{-1}$ & $5.8(4)$ & $6.92(2)$ & $7.87(1)$ & $6.10(3)$ \\
Total N & ${\mathrm{g} \cdot \mathrm{kg}^{-1}}$ & $0.52(4)$ & $0.61(2)$ & $0.77(1)$ & $0.53(3)$ \\
SOC & $\mathrm{t} \mathrm{Cha}^{-1}$ & $13.49(4)$ & $15.99(2)$ & $18.06(1)$ & $14.09(3)$ \\
Avail. P & $\mathrm{mg} \cdot \mathrm{kg}^{-1}$ & $4.74(4)$ & $7.17(1)$ & $6.77(2)$ & $5.55(3)$ \\
CEC & $\mathrm{C} \mathrm{mol} \mathrm{kg-1}^{-1}$ & $0.64(4)$ & $1.33(2)$ & $1.40(1)$ & $0.89(3)$ \\
Maize Grain yield & $\mathrm{tha}^{-1}$ & $2.05(4)$ & $2.61(1)$ & $2.57(2)$ & $2.20(3)$ \\
Total & & 29 & 13 & 13 & 22 \\
Rank & & 3 & 1 & 1 & 2 \\
\hline
\end{tabular}

Values in bracket and in red = scores between parameters, those in red and not in brackets = score totals and their ranks among treatments. Values in black represent means of parameters obtained from Tables in text. 


\section{Conclusions}

Soils of Northern Guinea Savanna of Nigeria are continuously and intensively cultivated, resulting in soil quality degradation, carbon stock depletion, accelerated soil erosion and soil nutrient depletion. Therefore, prudent use and management of organic matter in soils are more important now than ever before to meet the high demands for food and fiber production and satisfy the needs of an increasing world population and industrialization. Therefore, managing soils under intensive use and restoring degraded soils have become top priorities for a sustained agronomic and forestry production while conserving soil and water resources. Hence, this study "Tillage with Desmodium intortum and fertilizer rates for carbon stock and quality improvement of soils in Northern Guinea Savanna" is aimed at devising possible means of ameliorating identified problems using Zea mays as test crop under tillage practices, using Desmodium intortum as live mulch.

From this study, it was inferred that the significantly improved soil organic matter content under the minimum tillage practices (MDIC \& MDST) and zero tillage (MDNT) treatments when compared with conventional tillage with maize sole cropping (MC) accounted for the reduced bulk density values under the minimum tillage practices. Also, zero tillage practice (MDNT) sequestered significantly $(\mathrm{P}<0.05)$ higher carbon stock $\left(18.06 \mathrm{t} \mathrm{C} \mathrm{ha}^{-1}\right)$, followed by minimum tillage (MDIC) that sequestered $15.99 \mathrm{t} \mathrm{C} \mathrm{ha}^{-1}$ than the other treatments. Similarly, $100 \mathrm{~kg} \mathrm{~N} \mathrm{ha}^{-1}$ and $26 \mathrm{~kg} \mathrm{P} \mathrm{ha}^{-1}$ sequestered significantly higher carbon stock in soils than the other treatments to suggest this minimum tillage and/or zero tillage practices for farmer adoption and environmental sustainability. The MDNT treatment (zero tillage) imparted significantly higher CEC $(2.02 \mathrm{C} \mathrm{mol}$ $\mathrm{kg}^{-1}$ ) than other treatments followed by MDIC. Mean grain yields under the minimum tillage with Desmodium intercrops (MDIC) yielded 2.61 tha ${ }^{-1}$, MDNT yielded 2.57 tha $^{-1}$ and MDST yielded 2.20 tha $^{-1}$ to be preferred for sustainable maize grain production, mitigation of global warming, climate change and environmental conservation over the 2.05 tha $^{-1}$ yield of mono crop maize under conventional tillage (MC). In conclusion, net assessment of the minimum data set (MDS) effect on the soil resulted in highest grain yield of 2.61 tha $^{-1}$ under MDIC and MDNT, followed by MDST and least under MC. Therefore, total score of the quality assessment judged least score (best) values of 13 under $\mathrm{MDIC}$ and MDNT; thus best soil quality $\left(\mathrm{SQ}_{1}\right)$ was ascribed to the minimum tillage with $D$. intortum intercrop and relayed (MDIC) and Zero tillage with $D$. intortum (MDNT) treatments. Maize Strip cropped with $D$. intortum treatment (MDST) was ranked $\mathrm{SQ}_{2}$. The Maize under conventional tillage (MC) performed very poorly in the quality assessment and was ranked $\mathrm{SQ}_{3}$.

\section{Acknowledgements}

The authors are immensely appreciative of logistic support from the Institute for Agricultural Research, Faculty of Agriculture, Ahmadu Bello University, Zaria 
and the International Center of Insect Physiology and Ecology (ICIPE), Kenya towards this research and publication.

\section{Conflicts of Interest}

The authors declare no conflicts of interest regarding the publication of this paper.

\section{References}

[1] Blessing, A.D. (2018) Tillage Management with Desmodium intortum and Fertilizer Rates for Quality Improvement of a Northern Guinea Savanna Alfisol, Samaru, Nigeria.

[2] Blanco, H. and Lal, R. (2008) Principles of Soil Conservation and Management. Springer, New York.

[3] FAO (2008) The State of Food and Agriculture. Biofeuls: Prospects, Risks and Opportunity. Food and Agriculture Organization of the United Nations, Rome.

[4] Chude, V.O. and Odunze, A.C. (2015) Priorities for Sustainable Soil Management in Nigeria. In: Botang, F. and Ndeso-Atanga, A., Eds., Nature \& Faune: Food and Agriculture Organization of the United Nation. Sustainable Soil Management, FAO Regional Office for Africa: Keyto Food Security and Nutrition in Africa, Vol. 30, Issue $1,18-21$.

[5] Odunze, A.C., Haruna, H. and Oyinlola, E.Y. (2019) Slope Position and Land Use Effect on Select Soil Properties, Quality and Carbon Stock in Surface Soils at Afaka Forest Areas, Northern Guinea Savanna of Nigeria. Current Journal of Applied Science and Technology, 32, 1-13. http://www.sciencedomain.org/issue/4351 https://doi.org/10.9734/CJAST/2019/46375

[6] Logah, V., Ewusi-Mensah, N. and Tetteh, F.K.M. (2011) Soil Organic Carbon and Crop Yield under Different Soil Amendments and Cropping Systems in the Semi-Deciduous Forest Zone of Ghana. Journal of Plant Sciences, 6, 165-173. https://doi.org/10.3923/jps.2011.165.173

[7] Yeates, G.W., Hawke, M.F. and Rijkse, W.C. (2000) Changes in Soil Fauna and Soil Conditions under Pinus radiata Agroforestry Regimes during a 25 Year Tree Rotation. Biology and Fertility of Soils, 31, 391406. https://doi.org/10.1007/s003749900186

[8] Odunze, A.C., Wu, J., Liu, S., Zhu, H., Ge, T., Wang, Y. and Luo, Q. (2012) Soil Quality Changes and Quality Status: A Case Study of the Subtropical China Region Ultisols. British Journal of Environment and Climate Change, 2, 37-57. https://doi.org/10.9734/BJECC/2012/1148

[9] Odunze, A.C., Wu, J., Liu, S., Zhu, H., Ge, T., Wang, Y. and Luo, Q. (2012) Soil Quality Response to Long-Term Nutrients and Management Practice to Potato Production in Ultisols of Subtropical China. Journal of Environment and Natural Resources Research, 2, 129-139. https://doi.org/10.5539/enrr.v2n1p129

[10] Chidowe, O.A., Musa, Y.D. and Abdulkadir, A. (2017) Soil Quality, Carbon Sequestration and Yield of Maize (Zea mays L.) under Maize/Legume Cropping System in Alfisols of a Savanna Zone, Nigeria. American Journal of Climate Change, 6, $622-642$

[11] Chidowe, O.A., Musa, Y.D. and Abdulkadir, A. (2017) Soil Organic Carbon Concentrations and Stocks under Maize/Legume Cropping System in Alfisols of a Savanna Zone, Nigeria. British Journal of Applied Science \& Technology, 21, 1-12. 
https://doi.org/10.9734/BJAST/2017/32538

[12] Dogniméton, S., Ayolié, K., Zro, F.G.B., Yéboua, F.Y., Kouadio, H.K.-K., Bakayoko, S., Angui, P.T. and Kouadio, J.Y. (2015) Impact of Organic Fertilization on Maize (Zea mays L.) Production in a Ferralitic Soil of Centre-West Côte D'ivoire. Journal of Experimental Biology and Agricultural Sciences, 3, 556-565.

[13] Laishram, J., Saxena, K.G., Maikhuri, R.K. and Rao, K.S. (2012) Soil Quality and Soil Health: A Review. International Journal of Ecology and Environmental Sciences, 38, 19-37.

[14] Smith, O.H., Peterson, G.W. and Needleman (2000) Environmental Indicators of Agroecosystems. Advances in Agronomy, 69, 75-97.

https://doi.org/10.1016/S0065-2113(08)60947-5

[15] Chude, V.O., Malgwi, W.B., Amapu, I.Y. and Ano, O.A. (2011) Manual on Soil Fertility Assessment. Federal Fertilizer Department in Collaboration with National Programme for Food and Security, Abuja. 62 p.

[16] Yéo, Y.A. (2011) Analyse de la compétivité du mais locale en Cote d'Ivoire, Elève ingénieur Agroéconomiste de la 41e promotion ENSA Boubacar Diallo, MSU. 10.

[17] Odunze, A.C. (2011) Use of Meteorological Data in Agriculture. In: Training Manual on "Training of Monitoring and Evaluation Staff Handling Weather Data Collection of Kaduna State Agricultural Development", Farming Systems Research Program, Institute for Agricultural Research/Ahmadu Bello University, Zaria, FRSP Special Publication, 1-9.

[18] Oluwsemire, K.O. and Alabi, S.O. (2004) Ecological Impact of Changing Rainfall Pattern, Soil Process and Environmental Pollution in Sudan and Northern Guinea Savanna Agro Ecological Zones of Nigeria. Soil Resources, 5, 23-31. https://doi.org/10.4314/njser.v5i1.28387

[19] USDA (1975) Soil Taxonomy. A Basic System of Soil Classification for Making and Interpreting Soil Surveys. Washington DC, 745.

[20] Ogunwole, J.O. and Ogunleye, P.O. (2004) Surface Aggregation, Trace, and Heavy Metal Environment under Long-Term Application of Farmyard Manure and Mineral Fertilizers Contamination in Soil. Soil Science and Plant Analysis, 36, 1506-1516. https://doi.org/10.1081/CSS-120038551

[21] FAO-UNESCO Legend (1990) Soil Map of the World. Revised Legend. Food and Agricultural Organization of the United Nations, Rome.

[22] Jones, M.J. and Wild, W. (1975) Soils of the West African Savanna. Technical Communications No. 55, Commonwealth Bureau of Soils, CAB, Harpenden.

[23] Odunze, A.C. (2003) Effect of Forage Legumes Incorporation on Selected Soil Properties in the Northern Guinea Savanna of Nigeria. Journal of Sustainable Agriculture, 22, 102-112. https://doi.org/10.1300/J064v22n01_08

[24] Odunze, A.C. and Kureh, I. (2007) Land Use Limitations and Management Option for a Savanna Zone Alfisol. Nigerian Journal of Soil and Environmental Research, 7, 70-81. https://doi.org/10.4314/njser.v7i1.28420

[25] Chikoye, D., Ellis-Jones, J., Tarawali, G. and Lum, A.F. (2004) Reducing Poverty through Improved Striga Control. Proceedings of the 2 nd Striga Management, Zaria, 8-9 September 2004, 62-82.

[26] Hassanali, A., Haeeen, H., Khan, Z.R., Pickett, J.A. and Woodcook, C.M. (2009) Integrated Pest Management: The Push-Pull Approach for Controlling Insect Pests and Weeds of Cereals and Its Potential for Other Agricultural Systems Including Animal Husbandry. Philosophical Transactions of the Royal Society B, 363, 
611-621. https://doi.org/10.1098/rstb.2007.2173

[27] Khan, Z.R., Charles, A.O., Midega, T., Bruce, J.A., Hooper, A.M. and Pickett, J.A. (2010) Exploiting Phytochemicals for Developing a "Push-Pull" Crop Protection Strategy for Cereal Farmers in Africa. Journal of Experimental Botany, 61, 4196-4196. https://doi.org/10.1093/jxb/erq229

[28] Odunze, A.C. (2013) Push-Pull Nigeria Project Training Report: Through Integrated Striga Management in Africa (ISMA). Training Workshop on Sustainable Striga Control for Poor Farmers in Africa: The Push-Pull Nigeria Project 2012-2013, Kenya, 2nd May 2013.

[29] Henderson, W.H., Laland, H. and Duquette, M. (1993) Soil Reaction and Exchangeable. In: Carter, M.R., Ed., Soil Sampling and Methods of Analysis, Can. Society of Soil Science, Lewis Publishers, London, 141-145.

[30] Nelson, D.W. and Sommers, L.E. (1982) Total Carbon, Organic Carbon and Organic Matter. In: Page, et al., Eds., Methods of Soil Analysis, Part 2, Chemical and Microbiological Properties, 2nd Edition, Agron. 9, American Society of Agronomy, Madison, 539-580.

[31] Anikwe, M.A.N. (2006) Soil Quality Assessment and Monitoring: A Review of Current Research Effort.

[32] Bremmer, J.M. and Mulvaney, C.S. (1982) Nitrogen Total. In: Page, et al., Eds., Methods of Soil Analysis, Part 2, Chemical and Microbiological Properties, 2nd Edition, Agron. 9, American Society of Agronomy, Madison, 595-624.

[33] Brady, R.H. and Kurtz, L.T. (1945) Determination of Total Organic and Available Forms of Phosphorus in Soils. Soil Science, 59, 36-45. https://doi.org/10.1097/00010694-194501000-00006

[34] Jackson, I.J. (1989) Climate, Water and Agriculture in the Tropics. 2nd Edition, John Wiley and Sons Inc., New York, 377.

[35] Chapman, H.D. (1965) Total Exchangeable Bases. In: Black, C.A., Ed., Methods of Soil Analysis Part 11, American Society of Agronomy, Madison, Vol. 56, 902-904.

[36] Agbenin, J.O. (1995) Laboratory Manual for Soil and Plant Analysis (Selected Methods and Data Analysis) Aggregate and Particle Associated Organic Carbon under Different Land Uses in Nepal. Soil Science Society of America Journal, 71, 94-1203.

[37] Chapman, H.D. (1982) Cation Exchange Capacity. In: Black, C.A., Ed., Methods of Soil Analysis, Part 2, Number 9 in the Series Agronomy, American Society of Agronomy, Madison, 891-901.

[38] Anderson, J.M. and Ingram, J.I.S. (1993) Tropical Soil Biology and Fertility. In: $A$ Handbook of Methods, 2nd Edition, C.A.B. International, Wallingford, 221.

[39] Rhoades, J.D. (1982) Cation Exchange Capacity. In: Page, et al., Eds., Methods of Soil Analysis, Part 2, Chemical and Microbiological Properties, 2nd Edition, Agron. 9, American Society of Agronomy, Madison, 149-158.

[40] Post, W.M. and Kwon, K.C. (2000) Soil Carbon Sequestration and Land Use Change: Processes and Potential. Global Change Biology, 6, 317327. https://doi.org/10.1046/j.1365-2486.2000.00308.x

[41] Doran, J.W., Sarrantonio, M. and Liebig, M. (1996) Soil Health and Sustainability. Advances in Agronomy, 56, 1-54. https://doi.org/10.1016/S0065-2113(08)60178-9

[42] Doran, J.W. and Safley, M. (1997) Defining and Assessing Soil Health and Sustainable Productivity. In: Pankhurst, C., et al., Eds., Biological Indicators of Soil Health, CAB International, Wallingford, 1-28.

[43] Doran, J.W. and Parkin, T.B. (1994) Defining and Assessing Soil Quality. In: Doran, 
J.W., Coleman, D.C., Bezdicek, D.F. and Stewart, B.A., Eds., Defining Soil Quality for a Sustainable Environment, Soil Science Society of America Special Publication, Soil Science Society of America, Madison, Vol. 35, 3-21. https://doi.org/10.2136/sssaspecpub35.c1

[44] Andrew, S.S. and Carroll, C.R. (2001) Designing a Soil Quality Assessment Tool for Sustainable Agroecosystem. Ecological Applications, 11, 1573-1585. https://doi.org/10.1890/1051-0761(2001)011[1573:DASQAT]2.0.CO;2

[45] Parr, J.F., Papendick, R.I., Hornick, S.B. and Meyer, R.E. (1992) Soil Quality: Attributes and Relationship to Alternative and Sustainable Agriculture. American Journal of Alternative Agriculture, 7, 5-11. https://doi.org/10.1017/S0889189300004367

[46] SAS (2011) Statistical Package. SAS Mixed Model. SAS Institute, Cary.

[47] Chidowe, O.A., Destiny, M.Y. and Abdulkadir, A. (2018) Soil Organic Carbon Concentrations and Stocks under Maize/Legume Cropping System in Alfisols of a Savanna Zone, Nigeria. British Journal of Applied Science \& Technology, 21, 1-12. https://doi.org/10.9734/BJAST/2017/32538

[48] Odunze, A.C. (2002) Mulching Practice for Soil Erosion Control and Grain Yield of Maize. Journal of Sustainable Agriculture, 20, 31-40. https://doi.org/10.1300/J064v20n02_05

[49] Chidowe, O.A. (2015) Soil Conservation for Mitigation and Adaptation to a Changing Climate: Sustainable Solutions in the Nigerian Savanna Ecology. International Journal of Plant \& Soil Science, 8, 1-12. http://www.sciencedomain.org https://doi.org/10.9734/IJPSS/2015/19628 